\title{
Dog Mastocytoma Cells Produce Transforming Growth Factor Beta
}

Daniel W. Pennington, Alfredo R. Lopez, Paul S. Thomas, Caroline Peck, and Warren M. Gold

Department of Medicine, and Cardiovascular Research Institute, University of California, San Francisco, San Francisco, California 94143

\begin{abstract}
Transforming growth factor- $\beta$ (TGF $\beta$ ) promotes deposition of extracellular matrix and is associated with fibrotic conditions both in experimental animals and in humans. Although a role for mast cells has been suspected in the pathogenesis of fibrosis, no potent mediator capable of stimulating fibroblast growth or extracellular matrix deposition has been identified in mast cell supernatants. We report here the constitutive production of TGF $\beta_{1}$ by four dog mastocytoma cell lines. TGF $\beta_{1}$ was identified by characteristic biologic activity, blockade of biologic effect by specific neutralizing antibody, and by recognition of a band with the appropriate migration by western blot. TGF $\beta_{1}$ mRNA, but not TGF $\beta_{2}$ or TGF $\beta_{3}$ mRNA, was also produced constitutively by all four cell lines. Quantitation by bioassay revealed baseline TGF $\beta$ secretion of $\sim 1 \mathrm{ng} / 1^{6}$ cells over 48 h. Stimulation of mastocytoma cells with phorbol ester increased the rate of release of TGF $\beta_{1}$, most markedly in the first 30 min after stimulation, without increasing TGF $\beta_{1}$ mRNA. Dog mastocytoma cells produced TGF $\beta_{1}$ primarily in a latent form, inactive until treated with acid. Both pure TGF $\beta_{1}$ and TGF $\beta$-containing mastocytoma cell-conditioned media inhibited mitogenesis and proliferation in dog mastocytoma cell lines, suggesting that mast cell tumor lines would not grow preferentially based on their ability to produce TGF $\beta$. These studies may make possible further investigation of the mechanism by which mast cells contribute to the induction of fibrosis. (J. Clin. Invest. 1992. 90:35-41.) Key words: mast cell • fibrosis • inflammation • wound healing
\end{abstract}

\section{Introduction}

Members of the transforming growth factor- $\beta$ (TGF $\beta)^{1}$ family of signaling peptides are released from platelets and produced by many cell types in culture including macrophages, monocytes (1), neutrophils (2), T lymphocytes (3), and fibroblasts (4). These peptides have a variety of inflammatory and immunomodulatory effects, and alter the growth and function of a wide variety of cells (5). TGF $\beta$ appears to play an important part in the pathogenesis of fibrosis, since these peptides stimu-

Address correspondence to Warren M. Gold, Box 0130, Cardiovascular Research Institute, University of California, San Francisco, San Francisco, CA 94143.

Received for publication 16 July 1990 and in revised form 25 February 1992.

1. Abbreviations used in this paper: $\mathrm{CMF}$, calcium- and magnesiumfree; $4 \alpha \mathrm{PDB}, 4-\alpha$-phorbol 12, 13-dibutyrate; GAP, glyceraldehyde 3 -phosphate dehydrogenase; TGF $\beta$, transforming growth factor- $\beta$.

J. Clin. Invest.

(C) The American Society for Clinical Investigation, Inc.

$0021-9738 / 92 / 07 / 0035 / 07 \quad \$ 2.00$

Volume 90, July 1992, 35-41 late production of extracellular matrix $(6,7)$ and inhibit the formation of extracellular proteases (8). In animal models of pulmonary fibrosis, large increases in TGF $\beta$ are seen shortly before fibrosis begins (9-11). Finally, abnormally large amounts of TGF $\beta$ are observed in clinical specimens obtained from humans with fibrotic diseases of the lung $(12,13)$, eye (14), joints (15), and skin (16).

Mast cells, in addition to the well-known part they play in allergic reactions, may contribute to the pathogenesis of a variety of nonallergic inflammatory conditions (17). In particular, histologic observations have led to the hypothesis that mast cells play an important part in many fibrotic reactions (18-26). Potential mast cell-derived mediators of the fibrotic response include the mast cell protease tryptase, which has recently been found to stimulate fibroblast proliferation (27), as well as a partially characterized fibroblast growth-stimulating activity distinct both from tryptase and from TGF $\beta$ (28). Despite these observations, mast cells are not known to elaborate mediators capable of inducing extracellular matrix deposition. We have characterized previously four dog mastocytoma cell lines (2931). Despite their neoplastic phenotype, these cells display a number of mast cell-specific characteristics. They express high affinity IgE receptors and beta-adrenergic receptors, and release typical mast cell mediators including histamine, proteases, prostaglandins, leukotrienes, and proteoglycans in response to specific antigen or calcium ionophore. To examine the role of mast cells in fibrotic reactions, we addressed the hypothesis that mast cells produce fibrogenic peptide growth factors. We report here that mastocytoma cells secrete TGF $\beta_{1}$. We suggest that mast cells, by producing TGF $\beta_{1}$, may contribute to the pathogenesis of inflammation and fibrosis.

\section{Methods}

Materials. Unless specified, all chemicals were from Sigma Chemical Co. (St. Louis, MO). Phorbol myristate acetate (PMA) was obtained from ICN Biochemicals, Cleveland, $\mathrm{OH}$, and 4- $\alpha$-phorbol 12,13-dibutyrate ( $4 \alpha \mathrm{PDB})$ from LC Services, Woburn, MA. TGF $\beta_{1}, \mathrm{TGF} \beta_{2}$, antiTGF $\beta$, and anti-TGF $\beta_{2}$ were purchased from R\&D Systems, Inc., Minneapolis, $\mathrm{MN}$.

Cell culture. Mastocytoma cells were maintained in passage in tissue culture $\left(C_{1}, C_{2}\right.$, and $B R$ cell lines) or in athymic nude mice ( $G$ and $\mathrm{BR}$ cell lines). The cell lines proliferate in tissue culture in DME H16 mixed $50 \%$ with Ham's F12 supplemented with $2 \%$ dog or calf serum, penicillin $(100 \mathrm{U} / \mathrm{ml})$, streptomycin $(100 \mu \mathrm{g} / \mathrm{ml}), 2 \mathrm{mM}$ glutamine, 1.6 $\mathrm{mM}$ histidine, $25 \mathrm{mM}$ Hepes ( $\mathrm{pH}$ 7.4) (normal growth medium). Cells maintained in this medium were split 1:4 at weekly intervals. Mastocytoma cells were dissociated from nude mouse tumors by digestion with collagenase as previously reported $(30,31)$.

CCL-64 (Mv1Lu) mink lung epithelial cells were obtained from American Type Culture Collection, Rockville, MD, and were maintained in DME supplemented with $10 \%$ calf serum. All cells were maintained at $37^{\circ} \mathrm{C}$ in $5 \% \mathrm{CO}_{2}$.

Collection of conditioned media. Cultured mastocytoma cells growing in log phase in normal growth medium were washed twice with calcium- and magnesium-free (CMF) PBS and resuspended overnight 
at $4 \times 10^{6}$ cells $/ \mathrm{ml}$ in a T-150 flask (Corning Glass Inc., Corning, NY) in collection medium (normal growth medium except that BSA, 1-2 $\mathrm{mg} / \mathrm{ml}$, was substituted for serum). The following day cells were washed once more with CMF PBS and then suspended at the same density in collection medium. After $48 \mathrm{~h}$, the media were collected and centrifuged at $800 \mathrm{~g}$ for $5 \mathrm{~min}$ to remove suspended cells and debris and the conditioned media were stored at $-20^{\circ} \mathrm{C}$. For the $\mathrm{G}$ and BR cell lines, conditioned media were collected for $48 \mathrm{~h}$ after disaggregation from athymic nude mouse tumors. In some experiments, proteinase inhibitors (soybean trypsin inhibitor, aprotinin, leupeptin, and phosphoramidon, each at $20 \mu \mathrm{g} / \mathrm{ml}$ ) were added to the collection media.

Time course of TGF $\beta$ release and stimulation with phorbol ester. $\mathrm{C}_{2}$ cells growing in log phase were washed, suspended in collection medium, and stimulated with PMA ( $30 \mathrm{nM}$ final concentration). Supernatants were collected serially over $30 \mathrm{~min}, 2 \mathrm{~h}$, and $8 \mathrm{~h}$. At the end of each collection period, cells were removed from suspension by centrifugation and resuspended in fresh collection media containing PMA. Cell viability was always $>90 \%$ at the beginning of the experiment and $>85 \%$ at the end of supernatant collection. Supernatants were dialyzed to remove stimulating agents $(3.5-\mathrm{kD}$ cutoff membrane soaked overnight in BSA $1 \mathrm{mg} / \mathrm{ml})$ against Hepes-buffered saline $(140 \mathrm{mM} \mathrm{NaCl}$, $20 \mathrm{mM}$ HEPES, $\mathrm{pH}$ 7.4) when preservation of latent TGF $\beta$ was desired, or against $1 \mathrm{M}$ acetic acid followed by $4 \mathrm{mM} \mathrm{HCl} / 140 \mathrm{mM} \mathrm{NaCl}$ to activate TGF $\beta$ for bioassay. Controls were carried out in parallel: $(a)$ $4 \alpha \mathrm{PDB}$ ( $30 \mathrm{nM}$ ), an ester which does not activate protein kinase $\mathrm{C}$, was substituted for PMA. Both phorbol esters were made as stocks dissolved in DMSO (final concentration of DMSO in culture medium $0.1 \%)$. (b) DMSO $(0.1 \%)$ was used as a vehicle control. (c) Untreated collection medium. Cell-free controls were also performed: collection medium alone or collection medium spiked with PMA (30 nM) were dialyzed and assayed in parallel.

CCL-64 bioassay was modified from Danielpour (32) and detects $\operatorname{TGF} \beta_{1}$, TGF $\beta_{2}$, or TGF $\beta_{3}(33)$ as potent inhibitors of DNA synthesis in epithelial cells. CCL- 64 cells were plated in DME supplemented with $10 \%$ calf serum. Subconfluent cells were trypsinized, resuspended in $10 \%$ calf serum, pelleted at $800 \mathrm{~g}$, and washed once with assay buffer (DME supplemented with $0.2 \%$ FCS, $10 \mathrm{mM}$ Hepes, $\mathrm{pH} 7.4$, penicillin $(100 \mathrm{U} / \mathrm{ml})$ and streptomycin $(100 \mu \mathrm{g} / \mathrm{ml})$. They were then resuspended in assay buffer and seeded at $5 \times 10^{4}$ in $0.5 \mathrm{ml}$ per well in 24-well plates (Costar Corp., Cambridge, MA). (The assay was found to be severalfold less sensitive when carried out in tissue culture plates; Falcon Labware, Becton, Dickinson \& Co., Oxnard, CA). After $1 \mathrm{~h}$, purified TGF $\beta_{1}$ or samples of unconcentrated mastocytoma cell-conditioned media were added. To assess presence of latent TGF $\beta$, conditioned media assays were performed with or without transient acidification immediately before bioassay. Acidification was carried out by adding $0.1 \mathrm{vol} 1 \mathrm{~N} \mathrm{HCl}$ for $5 \mathrm{~min}$ at $23^{\circ} \mathrm{C}$, followed by addition of $0.1 \mathrm{vol} 1$ $\mathrm{N} \mathrm{NaOH}$. For antibody inhibition studies, neutralizing antibody was added to wells containing CCL-64 cells immediately before addition of the test material. After $20 \mathrm{~h}$ incubation with test samples, [ ${ }^{3} \mathrm{H}$-methyl] thymidine $(56 \mathrm{Ci} / \mathrm{mmol} ; \mathrm{ICN})$ was added to a final activity of $0.5 \mu \mathrm{Ci} /$ $\mathrm{ml}$ for $4 \mathrm{~h}$. The cells were washed with CMF PBS, lysed with $1 \mathrm{ml} 2 \%$ SDS, and the lysate precipitated by adding $1 \mathrm{ml} 4 \%$ perchloric acid. The cell lysate was filtered through GF/A glass fiber filters (Whatman Inc., Clifton, NJ). The filters were washed with $2 \%$ perchloric acid and $95 \%$ ethanol. Incorporation of the label was quantitated by scintillation counting of the filters in aqueous scintillation fluid.

The concentration of conditioned medium required to cause halfmaximal inhibition of thymidine incorporation was determined for each sample, and compared with the quantity of pure TGF $\beta_{1}$ necessary to produce the same effect. Lyophilized TGF $\beta_{1}$ was recovered by dissolution in PBS $/ 100 \mu \mathrm{g}$ per ml BSA.

Western blot. Cultured $\mathrm{C}_{2}$ or BR mastocytoma cells $\left(5 \times 10^{7}\right.$ cells $)$ were washed overnight as for conditioned media collection, then pelleted and extracted with acid/ethanol/PMSF. Proteins precipitated with ethanol and anhydrous ethyl ether were redissolved in acetic acid as described (34). Acetic acid-soluble material ( $5 \mu \mathrm{g} /$ lane, determined by Coomassie $\mathrm{G}$ binding using BSA as a standard) was boiled for $5 \mathrm{~min}$ in SDS-sample buffer containing $10 \mathrm{mM}$ dithiothreitol, and electrophoresed through a 4-20\% gradient polyacrylamide gel (Bio-Rad Laboratories, Richmond, CA). Proteins were electroblotted onto polyvinylidine difluoride membrane (Millipore Corp., Bedford, MA) and incubated with $2 \mu \mathrm{g} / \mathrm{ml}$ polyclonal anti-TGF $\beta$ raised in chickens (R\&D Systems, Inc.). Binding was detected with alkaline phosphatase-linked rabbit anti-chicken IgG (Sigma Chemical Co.). The membrane was incubated with a chemiluminescent substrate (Lumiphos 530; Boehringer Mannheim Corp., Indianapolis, IN) and exposed to radiographic film.

RNA isolation and separation. RNA was purified from cultured BR and $\mathrm{C}_{2}$ cells by $\mathrm{CsCl}$ gradient centrifugation followed by phenol/chloroform extraction and ethanol precipitation (35). Polyadenylated RNA was prepared by oligo deoxythymidine chromatography (36). For comparison, RNA was also harvested directly from mastocytomas grown in athymic nude mice, from liver, spleen, and PBMC obtained from healthy adult dogs, and from early passage dog skin fibroblasts grown in culture in $10 \%$ CS-supplemented medium. 10-20 $\mu \mathrm{g}$ of RNA were loaded onto a $1.4 \%$ agarose gel containing $17 \%$ formaldehyde, separated by electrophoresis and blotted onto nylon (Hybond $\AA$; Amersham Corp., Arlington Heights, IL) membrane. Size standards (RNA ladder; Bethesda Research Laboratories, Gaithersburg, MD) were run on the gel with the samples. To find out whether TGF $\beta$ mRNA was increased by stimulation of the cells with phorbol ester, PMA was added to cultured $\mathrm{C}_{2}$ cells in normal growth medium, cells were harvested at $20 \mathrm{~min}, 1,2,4,12$, and $24 \mathrm{~h}$ after addition of PMA, and RNA was purified for Northern blot analysis.

Preparation of DNA probes and hybridization. Cloned human cDNA for TGF $\beta_{1}$ and mouse cDNAs for TGF $\beta_{1}, \operatorname{TGF} \beta_{2}$, and TGF $\beta_{3}$ were obtained from Rik Derynck $(33,37,38)$ (Genentech Inc., South San Francisco, CA). The human glyceraldehyde 3-phosphate dehydrogenase (GAP) cDNA was obtained from American Type Culture Collection (39). The plasmids were introduced into appropriate bacterial hosts and isolated by standard techniques (40). For TGF $\beta_{1}$, a $1.2-\mathrm{kb}$ BamHI/HindIII fragment was used. The GAP cDNA fragment was released from the plasmid by digestion with PstI and EcoRI; the TGF $\beta_{2}$ probe was a $2.1-\mathrm{kb}$ fragment generated by HincII/EcoRI digestion; the $\mathrm{TGF} \beta_{3}$ probe was a 1.2-kb EcoRI fragment. Fragments were labeled with ${ }^{32} \mathrm{P}$ using a random priming kit (Amersham Corp.) to a sp act of $>10^{9} \mathrm{cpm} / \mu \mathrm{g}$. Hybridization was carried out at $42^{\circ} \mathrm{C}$ overnight in $50 \%$ formamide, $5 \times \mathrm{SSC}$. The filters were washed at $58^{\circ} \mathrm{C}$ in $0.1 \times \mathrm{SSC}$, $0.1 \%$ SDS for TGF $\beta_{1}$; at $60^{\circ} \mathrm{C}$ in $0.1 \times$ SSC, $0.1 \%$ SDS for GAP and then autoradiographed. Low stringency $\left(50^{\circ} \mathrm{C}, 1 \times \mathrm{SSC}, 0.1 \% \mathrm{SDS}\right)$ washes were carried out for TGF $\beta_{2}$ and TGF $\beta_{3}$. Stripping for rehybridization was carried out at $65^{\circ} \mathrm{C}$ in $5 \mathrm{mM}$ tris (pH 8); 1 mM EDTA; $0.1 \times$ Denhardt's solution, followed by rehybridization with GAP probe to control for inequality of RNA loading.

Mastocytoma cell mitogenesis and proliferation. Mitogenesis studies were done in a manner analogous to that used for CCL-64 cells. $\mathrm{C}_{1}$ and $\mathrm{C}_{2}$ mastocytoma cells growing in log phase in $5 \%$ allergic dog serum were washed twice in CMF PBS and suspended at $5 \times 10^{4}$ cells/ $0.5 \mathrm{ml}$ in 24-well culture dishes in normal growth medium, except that dog serum concentration was $0.2 \%$. After $1 \mathrm{~h}$, pure TGF $\beta_{1}$ or samples of mastocytoma cell-conditioned medium were added. After $20 \mathrm{~h}$ incubation, tritiated thymidine was added to each well at $0.5 \mu \mathrm{Ci} / \mathrm{ml}$ and incubation continued for $4 \mathrm{~h}$. Cells were harvested and thymidine incorporation assessed as noted above for CCL-64 cells, except that, because these cells are only partially adherent, SDS and perchloric acid were added directly to culture wells, and the entire mixture filtered.

To assess the effect of TGF $\beta_{1}$ on mastocytoma cell proliferation, $C_{1}$ and $\mathrm{C}_{2}$ mastocytoma cells were plated in six-well plates at $10^{5}$ cells $/ \mathrm{ml}$ in $0.2 \%$ allergic dog serum-supplemented medium. Various concentrations of TGF $\beta_{1}$ were added and the cultures were incubated without feeding or other manipulation for $7 \mathrm{~d}$. Duplicate wells were counted at 1-2-d intervals using a Coulter counter (Coulter Corp., Hialeah, FL).

Analysis of data. For mitogenesis studies, each experiment was carried out at least three times, using triplicate wells for analysis of each sample dilution. For cell proliferation studies, duplicate wells were 
A

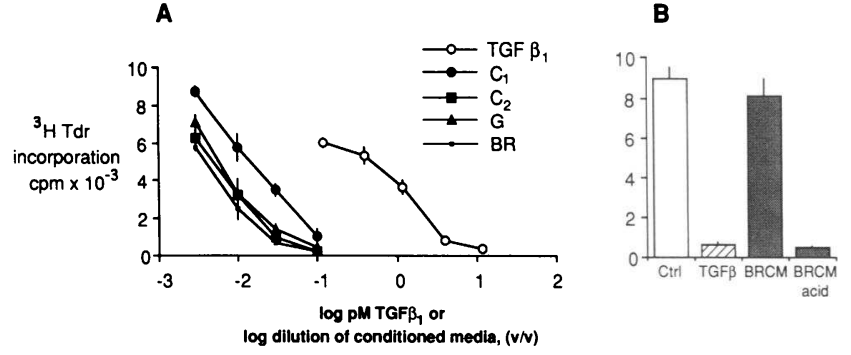

Figure 1. Mastocytoma cells produce TGF $\beta$-like bioactivity. $(A)$ TGF $\beta$-like activity from four dog mastocytoma cell lines. Crude conditioned media from four mastocytoma cell lines $\left(C_{1}, C_{2}, G, B R\right)$ were transiently acidified, neutralized, and added in serial dilutions to the CCL-64 mitogenesis assay. Human TGF $\beta_{1}$ served as a standard. $(B)$ Requirement for acid activation. Conditioned medium from cultured BR cells displays TGF $\beta$-like activity after transient acidification and neutralization. Ctrl, untreated CCL-64 cells; TGF, $4 \mathrm{pM}$ human $\mathrm{TGF} \beta_{1} ; B R C M$, unconcentrated conditioned medium from cultured BR mastocytoma cells ( $10 \% \mathrm{vol} / \mathrm{vol}) ; B R C M$ acid, conditioned medium activated by transient acidification. Mean \pm SD of triplicate determinations.

counted in three separate experiments. Data are expressed as mean \pm standard deviation. RNA hybridization and immunoblot experiments were carried out at least twice; typical experiments are shown.

\section{Results}

Identification of $T G F \beta_{I}$. Mastocytoma cell-conditioned media reproduced the effect of TGF $\beta_{1}$ in the CCL- 64 bioassay. TGF $\beta_{1}$ at concentrations of $0.6-1.0 \mathrm{pM}$ were found to inhibit $50 \%$ of baseline thymidine incorporation in CCL-64 cells under the experimental conditions described. Each of the four mastocytoma cell lines also produced growth-inhibitory activity, with concentration-response curves paralleling that of pure TGF $\beta_{1}$ (Fig. $1 A$ ). The amount of TGF $\beta$ activity produced by the BR, $\mathrm{G}$, and $\mathrm{C}_{2}$ cell lines was similar (media conditioned for $48 \mathrm{~h}$ by $4 \times 10^{6}$ cells $/ \mathrm{ml}$ contained $\sim 4 \mathrm{ng} / \mathrm{ml} \mathrm{TGF} \beta$ ). The $\mathrm{C}_{1}$ cell line produced two- to fourfold less activity.

To determine whether mastocytoma cells secreted TGF $\beta$ in a biologically active form, samples were tested with or without transient acidification. Minimal growth-inhibitory activity was seen without acidification (Fig. $1 \mathrm{~B}$ ). This small amount of activity occurred in samples containing high concentrations of latent $\mathrm{TGF} \beta$, and represented $<5 \%$ of the activity attainable after acidification. The addition of protease inhibitors to the collection media did not change the proportion of active TGF $\beta$ detected, nor did it affect the total amount of activity recovered by acidification (data not shown).

Neutralizing antibody against $\mathrm{TGF} \beta$ (with activity against both TGF $\beta_{1}$ and TGF $\beta_{2}$ ) blocked $90 \%$ of the growth-inhibitory activity in a concentration-dependent manner (Fig. 2). An antibody specific for TGF $\beta_{2}$ caused no detectable blockade. The specificity of these antibodies was confirmed using purified $\mathrm{TGF} \beta_{1}$ and $\mathrm{TGF} \beta_{2}$ (data not shown). Identification of the growth-inhibitory activity as TGF $\beta$ was confirmed by western blot (Fig. 3). When probed with anti-TGF $\beta, \mathrm{C}_{2}$ and $\mathrm{BR}$ cell extracts gave a band with similar migration to that of pure porcine $\mathrm{TGF} \beta_{1}$ under reducing conditions.
Time course of TGF $\beta$ release and stimulation with phorbol ester. In unstimulated $\mathrm{C}_{2}$ cells, the rate of $\mathrm{TGF} \beta$ release over the first $10.5 \mathrm{~h}$ of observation was found to be constant at $\sim 0.5 \mathrm{fmol} / 10^{6}$ cells per $\mathrm{h}$; this equals $0.6 \mathrm{ng} / 10^{6}$ cells per $48 \mathrm{~h}$ and approximates the rate of release observed during 48-h conditioned medium studies. Rapid stimulation of release of TGF $\beta$ was observed after stimulation with PMA; in six independent experiments, release of TGF $\beta$ in the first 30 min was increased $9.8 \pm 2.5$ fold (mean \pm SEM) over control by treatment with PMA. In the presence of anti-TGF $\beta$ (chicken IgY; R\&D Systems), the TGF $\beta$ effect in 30-min supernatants was completely reversed $(n=3)$. Control cultures treated in parallel with the inactive phorbol ester $4 \alpha \mathrm{PDB}(n=2)$ or with DMSO $(n=4)$ released TGF $\beta$ activity at a rate indistinguishable from untreated cells (Fig. 4). As with unstimulated cells, TGF $\beta$ was released primarily $(>95 \%)$ in a latent form after PMA stimulation.

$T G F \beta m R N A$ studies. RNA blot analysis was done to confirm the presence of TGF $\beta$ mRNA and to further determine which of the isoforms of TGF $\beta$ were produced by mastocytoma cells. Cultured $\mathrm{BR}$ and $\mathrm{C}_{2}$ cells constitutively expressed mRNA for TGF $\beta_{1}$ in amounts that were easily detectable in total cellu-

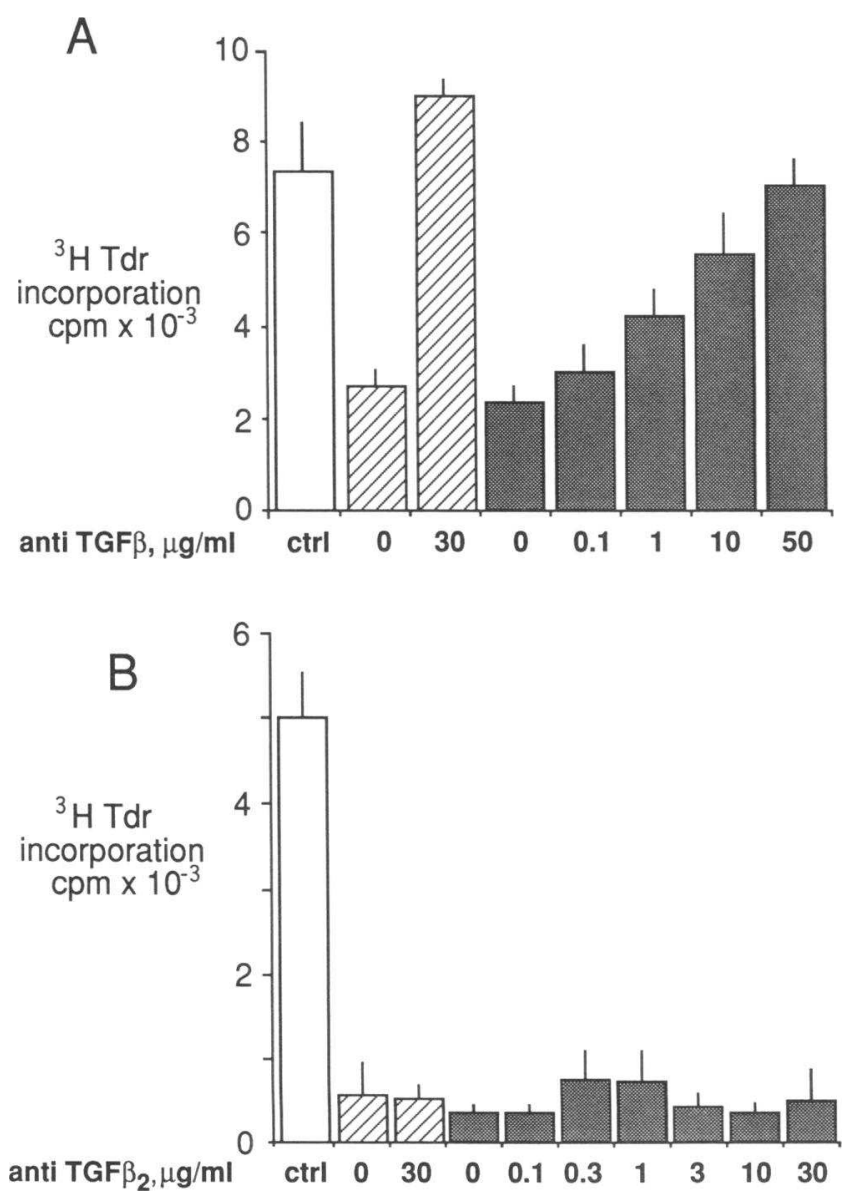

Figure 2. Blockade of biologic effect by neutralizing antibody. Serial dilutions of neutralizing antibody effective against TGF $\beta_{1}$ and TGF $\beta_{2}$ (anti TGF $; A$ ) or antibody specific for TGF $\beta_{2}\left(\right.$ anti $T G F \beta_{2} ; B$ ) were added to CCL-64 wells just before addition of pure TGF $\beta_{1}(4 \mathrm{pM})$ or (transiently acidified) $\mathrm{C}_{2}$ mastocytoma cell-conditioned medium $\left(\mathrm{C}_{2} \mathrm{CM}\right)$. Ctrl, untreated CCL-64 cells. Mean $\pm \mathrm{SD}$ of triplicate determinations. $\square$, Control, $0.2 \%$ FCS alone; $\operatorname{TGF}_{1} ;=\mathrm{C}_{2} \mathrm{CM}$. 


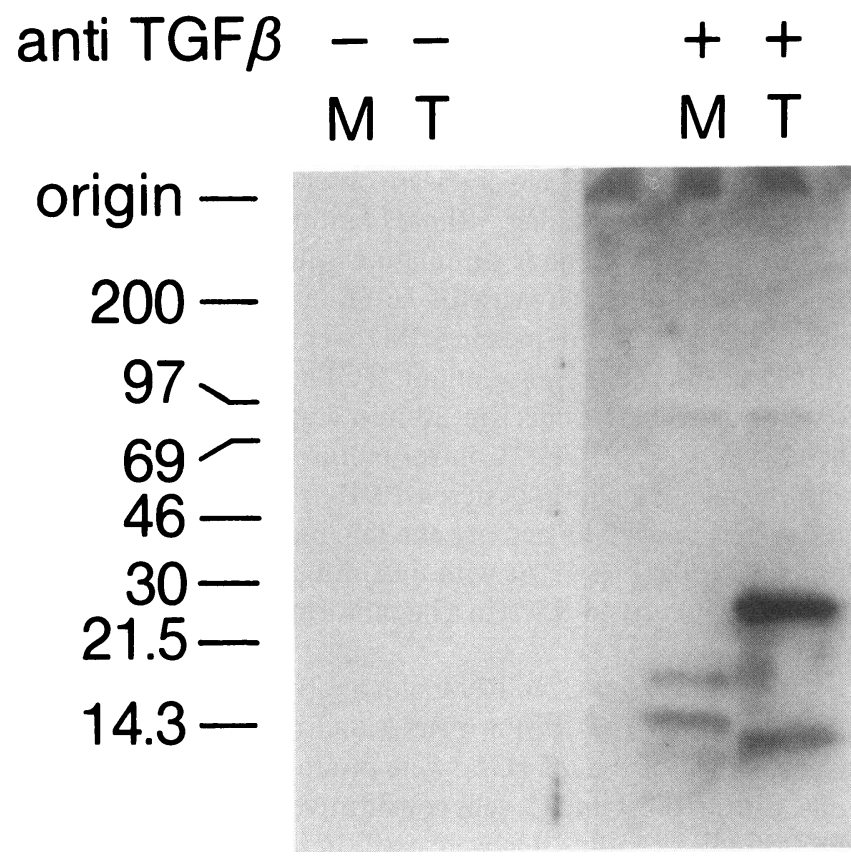

Figure 3. Western blot. $\mathrm{C}_{2}$ mastocytoma cell extract $(M ; 5 \mu \mathrm{g} /$ lane $)$ or porcine TGF $\beta_{1}(T ; 150 \mathrm{ng} /$ lane) were reduced with $10 \mathrm{mM}$ dithiothreitol, electrophoresed in duplicate through a 4-20\% gradient polyacrylamide gel, and blotted onto polyvinylidine difluoride membrane. The membrane was divided and incubated with or without polyclonal anti-TGF $\beta$ as shown. Antibody binding was detected using an alkaline phosphatase-based chemiluminescent system. Migration of size standards (Rainbow molecular weight markers; Amersham) is shown (in kilodaltons). Porcine TGF $\beta_{1}$ gives bands at 13 and $25 \mathrm{kD}$, representing incomplete reduction of the disulfide-linked dimer. The $18-\mathrm{kD}$ band appeared in the cell extract lanes without the primary antibody and represents nonspecific binding by the secondary antibody.

lar RNA; however, isolation of polyadenylated RNA was necessary to reduce nonspecific hybridization to $18 \mathrm{~S}$ ribosomal RNA. A strongly hybridizing band at $2.5-\mathrm{kb}$, and occasionally a much weaker band at $1.3-\mathrm{kb}$ were observed (Fig. 5, $A$ and $B$ ). In addition, RNA prepared directly from mastocytomas $\left(\mathrm{C}_{1}\right.$, $\mathrm{C}_{2}, \mathrm{BR}$, and $\mathrm{G}$ cell lines) grown in athymic nude mice was found to contain the $2.5-\mathrm{kb}$ TGF $\beta_{1}$ mRNA at levels similar to those seen in cultured cells. Cultured dog skin fibroblasts (passage $<10$ ) produced TGF $\beta_{1}$ mRNA at approximately the same level as the mastocytoma cells. Both spleen and PBMC showed two- to fourfold greater levels of TGF $\beta_{1}$ mRNA than mastocytoma cells, while in liver, TGF $\beta_{1}$ mRNA was barely detectable (data not shown). This pattern of expression is consistent with that observed in the mouse (41). No specific hybridization was observed in mastocytoma cell RNA using TGF $\beta_{2}$ or $\mathrm{TGF} \beta_{3}$ cDNA probes.

Northern blot studies of cultured $\mathrm{C}_{2}$ cells during the first 24 $h$ after stimulation with phorbol ester showed that the steady state level of TGF $\beta_{1}$ mRNA changed by less than twofold after stimulation with PMA.

Mastocytoma cell mitogenesis and proliferation. Next we asked whether TGF $\beta_{1}$ affected growth of mastocytoma cells, as was observed by Broide et al. using mouse bone marrowderived mast cells (42). In $C_{1}$ or $C_{2}$ mastocytoma cells, treatment with 2-4 pM TGF $\beta_{1}$ resulted in half-maximal inhibition of thymidine incorporation. Maximal inhibition of DNA syn-

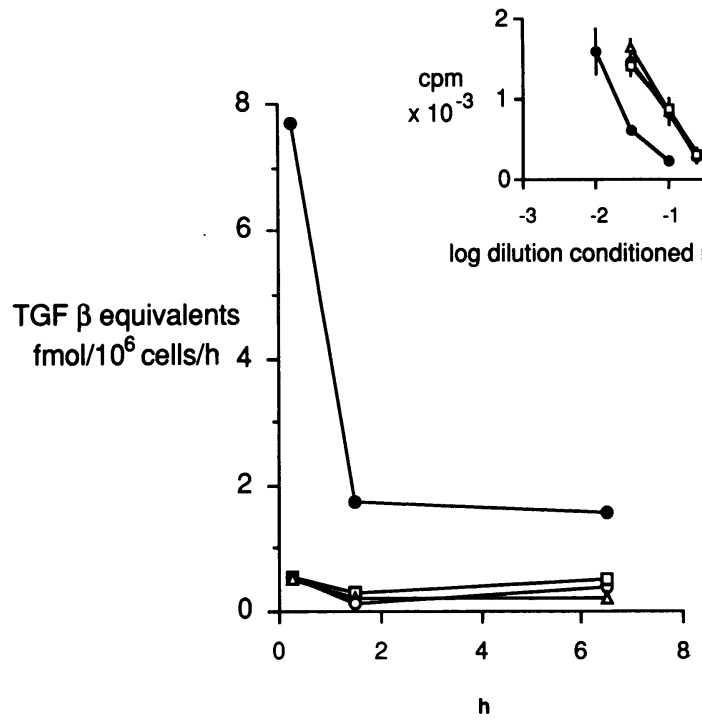

Figure 4. Time course of TGF $\beta$ release after treatment with phorbol ester. Serial supernatants were obtained from cultured $C_{2}$ mastocytoma cells after stimulation with PMA, the inactive phorbol ester $4 \alpha$ PDB, the vehicle DMSO, or no stimulation. After dialysis, TGF $\beta$ bioactivity was quantitated by bioassay and average rate of secretion of TGF $\beta$ over the interval calculated. Data are plotted at the midpoint of the time interval over which secreted materials were collected. (Inset) Concentration/response curves for 30-min supernatants; the leftward shift of the curve for the supernatant from PMA-stimulated cells reflects an eight-fold increase in release of

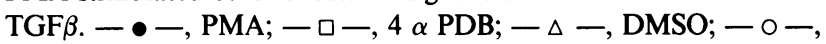
untreated.

thesis (to approximately $10 \%$ of the control value) was achieved by treatment with $100 \mathrm{pM}$ TGF $\beta_{1}$ (Fig. 6). This effect was reproduced by acidified $C_{2}$ cell-conditioned medium with a concentration-response curve parallel to that for pure TGF $\beta_{1}$. As in the CCL-64 cell assay, minimal inhibition of mitogenesis was observed with $\mathrm{C}_{2}$ cell-conditioned medium unless it was first transiently acidified.

Proliferation experiments using the $C_{1}$ and $C_{2}$ cell lines in $0.2 \%$ allergic dog serum-supplemented medium revealed growth of cells with doubling times of 42 and $38 \mathrm{~h}$, respectively. After addition of TGF $\beta_{1}$ to the cultures, a concentration-de-

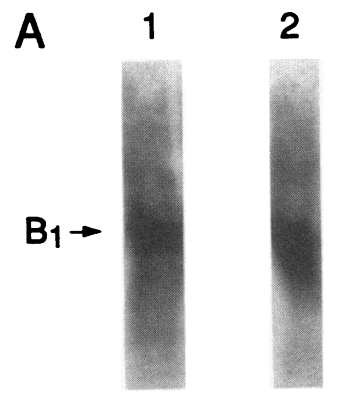

Figure 5. TGF $\beta_{1}$ mRNA content in dog mastocytoma cells and effect of PMA stimulation. $(A)$ Polyadenylated RNA $(10 \mu \mathrm{g})$ from cultured BR (1) and $\mathrm{C}_{2}(2)$ dog mastocytoma cells was run on a $1.4 \%$ agarose/formaldehyde gel, blotted onto nylon membrane,

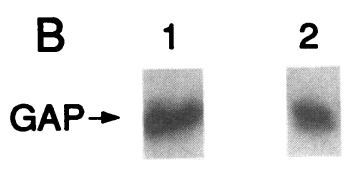
and probed with $(A)$ human TGF $\beta_{1}$ cDNA fragment $\left(B_{1} ; 2.5 \mathrm{~kb}\right)$, then stripped and probed with $(B)$ glyceraldehyde 3-phosphate dehydrogenase cDNA $(G A P ; 0.9 \mathrm{~kb})$. 
A

DNA SYNTHESIS

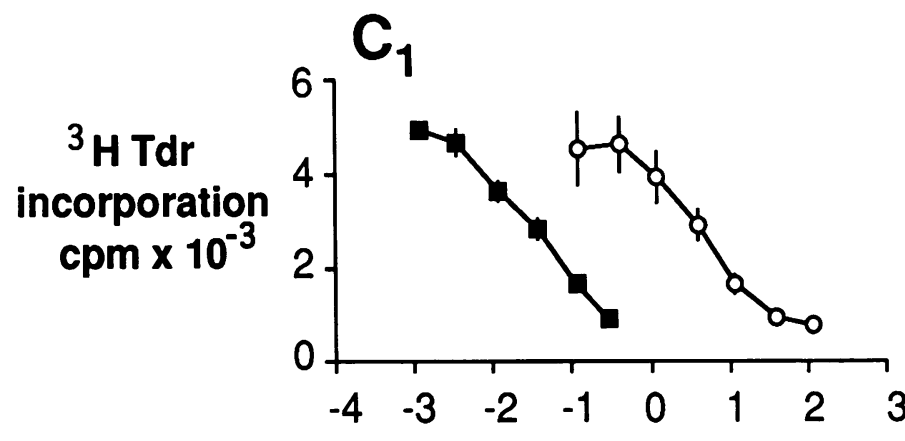

$\mathrm{C}_{2}$

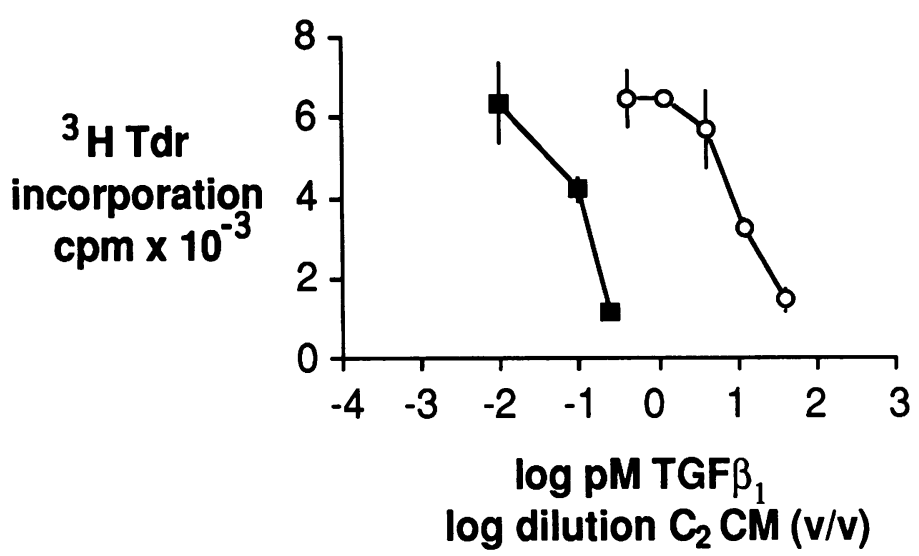

B CELL PROLIFERATION

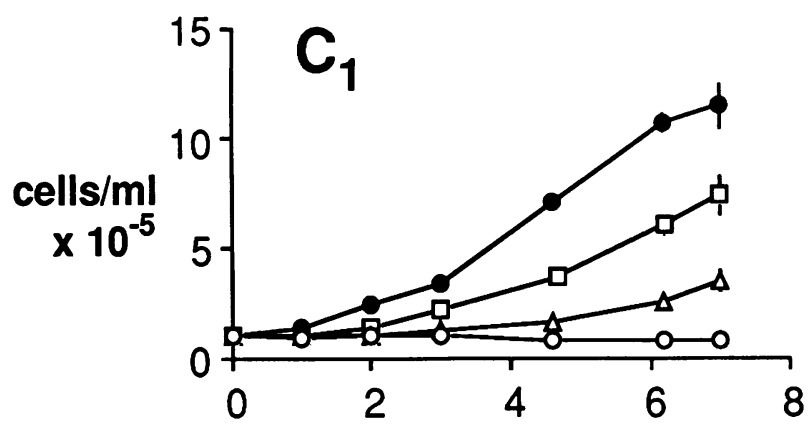

Figure 6. Inhibition of growth in $\mathrm{C}_{1}$ and $\mathrm{C}_{2}$ dog mastocytoma cells by TGF $\beta_{1}$ and by $\mathrm{C}_{2}$ cell-conditioned medium. DNA synthesis $(A)$ was assayed by tritiated thymidine incorporation for both cell lines after treatment with serial dilutions of TGF $\beta_{1}(---)$ or transiently acidified $C_{2}$ cellconditioned media $\left(\mathrm{C}_{2} \mathrm{CM} ;-\circ-\right)$. Proliferation $(B)$ of $\mathrm{C}_{1}$ and $\mathrm{C}_{2}$ cells was tested after treatment with $4 \mathrm{pM}(-\square-), 20 \mathrm{pM}(-\triangle-)$, or 100

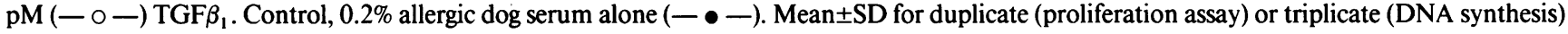
wells; typical of three experiments.

pendent decrease in growth rate of both cell lines was observed. $\mathrm{C}_{1}$ cells remained viable as assessed by erythrosin $\mathrm{B}$ exclusion at least $3 \mathrm{~d}$ after addition of $\operatorname{TGF} \beta_{1}$. In the $\mathrm{C}_{2}$ line, however, high concentrations of TGF $\beta(\geq 20 \mathrm{pM})$ produced widespread cell death (Fig. 6).

\section{Discussion}

We have shown that dog mastocytoma cells produce TGF $\beta_{1}$, as determined by biologic activity, blockade of the biological effect by specific neutralizing antibody, and characteristic migration and antibody recognition on western blot. Furthermore, these cells express mRNA which hybridizes with TGF $\beta_{1}$ cDNA. Unstimulated mastocytoma cells released $\sim 1 \mathrm{ng}$ TGF $\beta$ per $10^{6}$ cells over $48 \mathrm{~h}$; this is similar to the amount released by human monocytes after stimulation with LPS (1). Stimulation of mastocytoma cells with the phorbol ester PMA increased the secretion of TGF $\beta_{1}$ particularly over the first 30 min after stimulation, without increasing TGF $\beta_{1}$ mRNA. We also found that pure TGF $\beta_{1}$ inhibited mastocytoma cell DNA synthesis and cellular proliferation, and mastocytoma cell mitogenesis was inhibited by its own conditioned medium, once the conditioned medium was transiently acidified.

Mast cells are seen in greatly increased numbers in fibrotic lung tissue (18), in the involved skin in scleroderma (20), and in the synovium in rheumatoid arthritis (43). Induction of pulmonary fibrosis in animals by exposure to asbestos, bleomycin, or irradiation also results in mast cell activation and accumulation $(21,22,23,44)$. Murine mast cells studied in vitro stimulate fibroblast growth and synthesis of collagen and proteoglycan (25) by an unknown mechanism. By producing TGF $\beta_{1}$, mast cells may induce connective tissue deposition, and thereby contribute to tissue fibrosis.

TGF $\beta$ is released from platelets and from most cells in a high molecular weight, latent form which does not bind its receptor and is not biologically active (45). Enzymes such as plasmin, cathepsin $\mathrm{D}$, and endoglycosidase $\mathrm{F}$ release a fraction of the active factor in vitro $(46,47)$. Acidification is a convenient method for activation of TGF $\beta$ in vitro, although the $\mathrm{pH}$ required $(\sim 2)$ makes this mechanism of activation unlikely to 
occur in vivo. The physiologic activation of this peptide, presumably by proteolytic event(s), is considered an important regulatory mechanism. Mastocytoma cells released TGF $\beta_{1}$ primarily in a latent form, although small proportions $(<5 \%)$ of TGF $\beta$ activity could often be detected before acidification. It is unclear whether mastocytoma cells actually release a small amount of active TGF $\beta$, whether activation occurs during manipulation, (e.g., freezing and thawing, as has been previously reported [46]), or whether high molecular weight ("latent" TGF $\beta$ may have a small degree of intrinsic biologic activity, as suggested (48). Thus complete understanding of the contribution of mast cell-derived TGF $\beta$ must await better information regarding the control of TGF $\beta$ activation from the latent complex.

The three isoforms of TGF $\beta$ found in mammalian systems are structurally related molecules whose receptor binding and biological properties are similar (33), although cells produce widely varying proportions of TGF $\beta_{1}$ vs TGF $\beta_{2}$ (32). The bioassay we have employed is sensitive to any of the isoforms of TGF $\beta$. However, the absence of blockade by specific antiTGF $\beta_{2}$ suggests that mastocytoma cells produce little TGF $\beta_{2}$. RNA studies support the conclusion that mastocytoma cells, like most hematopoietic cells (unpublished observations), produce primarily $\mathrm{TGF} \beta_{1}$. Northern blot studies using TGF $\beta_{1}$ cDNA recognize only TGF $\beta_{1}$ at the stringencies used (unpublished observations). In addition, low stringency washes after hybridization with $\mathrm{TGF} \beta_{2}$ or TGF $\beta_{3}$ cDNAs gave no specific binding. Similar hybridization was observed using human or mouse TGF $\beta_{1}$ cDNA probes, suggesting that the lack of binding with mouse $\mathrm{TGF} \beta_{2}$ or TGF $\beta_{3} \mathrm{cDNAs}$ was not due to species cross-reactivity problems.

Increased release of TGF $\beta$ after stimulation with phorbol ester suggests that mast cell TGF $\beta$ release may be regulated by physiologic stimuli in vivo via mechanisms involving activation of protein kinase $C$. The pattern of release of TGF $\beta_{1}$ during continuous exposure to PMA was characteristic, i.e., rapid, early secretion followed by attainment of a new, modestly elevated steady state. Whether this pattern of secretion reflects release of material from intracellular stores, upregulation of growth factor synthesis, or both, is not yet clear. Neither the early, striking increase in release, however, nor the prolonged, more modest increase was accompanied by increases in TGF $\beta_{1}$ mRNA. This finding is similar to previous studies using monocytes, in which TGF $\beta$ mRNA was expressed constitutively, while secretion of growth factor was increased by stimulation of the cells with LPS (1).

The finding that the growth of mastocytoma cells is inhibited by TGF $\beta_{1}$ or by TGF $\beta$-containing mastocytoma cell-conditioned medium has at least two implications. First, it suggests that TGF $\beta_{1}$ production is not merely a result of mast cell neoplastic transformation, since mastocytoma cells remain sensitive to growth inhibition by this peptide. Therefore tumor cell lines would not proliferate preferentially based on their ability to produce TGF $\beta$. We have used dog mastocytoma cells because they are similar morphologically and biochemically to human mast cells (49). Since no ideal preparation exists for studies of human mast cells, dog mastocytoma cells provide a reliable mast cell preparation for experimental studies.

Secondly, this finding may contribute to the understanding of mast cell growth. Mast cells are capable of proliferation in situ in immunologic reactions (50), and, as mentioned, mast cells accumulate in tissue in a variety of pathologic conditions
(20-23, 43, 51). Proliferation of murine mast cells in vitro is stimulated by IL-3, IL-4, IL-9, and steel factor (52-55) whereas growth is inhibited by TGF $\beta_{1}$ (42) and granulocyte macrophage-colony-stimulating factor (GM-CSF) (56). It has been suggested previously that mast cells themselves may produce agents which limit mast cell proliferation or differentiation, and that GM-CSF may be a candidate mediator for this action $(56,57)$. Our results indicate that TGF $\beta_{1}$ must also be considered a possible mast cell autocrine growth inhibitor. Indeed, a recent report indicates that the mast cell growth response to IL-3 and IL-4 is inhibited by phorbol ester (58); it is possible that mast cell production of TGF $\beta$ may be involved in this growth inhibition. This is not a classical autocrine loop, however, since the peptide is released in a latent form which must be activated, possibly by a second cell type, before it inhibits mast cell growth.

TGF $\beta$ production seems not to be an artifact of cell culture, since TGF $\beta_{1}$ mRNA is expressed not only in cell culture, but in vivo in mast cell tumors as they grow in athymic nude mice. Similarly, TGF $\beta$ activity is released from cells both immediately after disaggregation from athymic nude mouse tumors and after prolonged culture in vitro.

In summary, we have shown that dog mastocytoma cells produce $\mathrm{TGF} \beta_{1}$. This is the first evidence of TGF $\beta$ production by mast-like cells. These findings suggest a mechanism by which mast cells may contribute to inflammatory and fibrotic reactions in many tissues and further suggests a possible autocrine regulatory role for $\mathrm{TGF} \beta_{1}$ in mast cell proliferation.

\section{Acknowledgments}

D. W. Pennington is supported by National Heart, Lung, and Blood Institute National Research Service Award HL-07697 and by an American Lung Association of San Francisco Strobel Medical Research Fund award. A. R. Lopez is a recipient of a Career Development Award of the Veterans Administration. W. M. Gold is supported by National Institutes of Health Program Project Grant HL-24136.

\section{References}

1. Assoian, R. K., B. E. Fleurdelys, H. C. Stevenson, P. J. Miller, D. K. Madtes, E. W. Raines, R. Ross, and M. B. Sporn. 1987. Expression and secretion of type $\beta$ transforming growth factor by activated human macrophages. Proc. Natl. Acad. Sci. USA. 84:6020-6024.

2. Grotendorst, G. R., G. Smale, and D. Pencev. 1989. Production of transforming growth factor beta by human peripheral blood monocytes and neutrophils. J. Cell. Physiol. 140:396-402.

3. Kehrl, J. H., L. M. Wakefield, A. B. Roberts, S. Jakowlew, M. AlvarezMon, R. Derynck, M. B. Sporn, and A. S. Fauci. 1986. Production of transforming growth factor $\beta$ by human T lymphocytes and its potential role in the regulation of T cell growth. J. Exp. Med. 163:1037-1050.

4. Needleman, B. W., J. Choi, A. Burrows-Mezu, and J. A. Fontana. 1990. Secretion and binding of transforming growth factor $\beta$ by scleroderma and normal dermal fibroblasts. Arthritis Rheum. 33:650-656.

5. Roberts, A. B., and M. B. Sporn. 1990. The transforming growth factor- $\beta$ s. In Peptide Growth Factors and Their Receptors. M. B. Sporn and A. B. Roberts, editors. Springer-Verlag, Heidelberg.

6. Fine, A., and R. H. Goldstein. 1987. The effect of transforming growth factor- $\beta$ on cell proliferation and collagen formation by lung fibroblasts. J. Biol. Chem. 262:3897-3902.

7. Liu, J.-M., and J. M. Davidson. 1988. The elastogenic effect of recombinant transforming growth factor- $\beta$ on porcine aortic smooth muscle cells. Biochem. Biophys. Res. Commun. 154:895-901.

8. Keski-Oja, J., R. Raghow, M. Sawdey, D. J. Loskutoff, A. E. Postlethwaite, A. H. Kang, and H. L. Moses. 1988. Regulation of mRNAs for type-1 plasminogen activator inhibitor, fibronectin and type I procollagen by transforming growth factor- $\beta$. J. Biol. Chem. 263:3111-3115.

9. Hoyt, D. G., and J. S. Lazo. 1988. Alterations in pulmonary mRNA encoding procollagens, fibronectin and transforming growth factor- $\beta$ precede bleomycin-induced pulmonary fibrosis in mice. J. Pharmacol. Exp. Ther. 246:765-771. 
10. Hoyt, D. G., and J. S. Lazo. 1989. Early increases in pulmonary mRNA encoding procollagens and transforming growth factor $\beta$ in mice sensitive to cyclophosphamide-induced pulmonary fibrosis. J. Pharmacol. Exp. Ther 249:38-43.

11. Khalil, N., O. Bereznay, M. Sporn, and A. H. Greenberg. 1989. Macrophage production of transforming growth factor $\beta$ and fibroblast collagen synthesis in chronic pulmonary inflammation. J. Exp. Med. 170:727-737.

12. Broekelmann, T. J., A. H. Limper, T. V. Colby, and J. A. McDonald. 1991. Transforming growth factor $\beta 1$ is present at sites of extracellular matrix gene expression in human pulmonary fibrosis. Proc. Natl. Acad. Sci. USA 88:6642-6646.

13. Khalil, N., R. N. O'Connor, H. W. Unruh, P. W. Warren, K. C. Flanders, A. Kemp, O. H. Bereznay, and A. H. Greenberg. 1991. Increased production and immunohistochemical localization of transforming growth factor $-\beta$ in idiopathic pulmonary fibrosis. Am. J. Respir. Cell Mol. Biol. 5:155-162.

14. Connor, T. B., A. B. Roberts, M. B. Sporn, D. Danielpour, L. L. Dart, R. G. Michels, S. de Bustros, C. Enger, H. Kato, and M. Lansing. 1989. Correlation of fibrosis and transforming growth factor $-\beta$ type 2 levels in the eye. J. Clin. Invest. 83:1661-1666.

15. Fava, R., N. Olsen, J. Keski-Oja, H. Moses, and T. Pincus. 1989. Active and latent forms of transforming growth factor $\beta$ in synovial effusions. J. Exp. Med. 169:291-296.

16. Kulozik, M., A. Hogg, B. Lankat-Buttgereit, and T. Kreig. 1990. Co-localization of transforming growth factor $\beta 2$ with $\alpha 1$ (1) procollagen mRNA in tissue sections of patients with systemic sclerosis. J. Clin. Invest. 86:917-922.

17. Bienenstock, J., M. Tomioka, R. Stead, P. Ernst, M. Jordana, J. Gauldie, J. Dolovich, and J. Denburg. 1987. Mast cell involvement in various inflammatory processes. Am. Rev. Respir. Dis. 135:S5-8.

18. Kawanami, O., V. J. Ferrans, J. D. Fulmer, and R. G. Crystal. 1979 Ultrastructure of pulmonary mast cells in patients with fibrotic lung disorders. Lab. Invest. 40:717-734.

19. Walls, A. F., A. R. Bennett, R. C. Godfrey, S. T. Holgate, and M. K Church. 1991. Mast cell tryptase and histamine concentration in bronchial alveolar lavage fluid from patients with interstitial lung disease. Clin. Sci. (Lond.) 81:183-188.

20. Hawkins, R. A., H. N. Claman, R. A. F. Clark, and J. C. Steigerwald. 1985 Increased dermal mast cell populations in progressive systemic sclerosis: a link in chronic fibrosis? Ann. Intern. Med. 102:182-186.

21. Goto, T., D. Befus, R. Low, and J. Bienenstock. 1984. Mast cell heterogeneity and hyperplasia in bleomycin-induced pulmonary fibrosis of rats. Am. Rev. Respir. Dis. 130:797-802.

22. Watanabe, S., K. Watanabe, T. Ohishi, M. Aiba, and K. Kageyama. 1974. Mast cells in the rat alveolar septa undergoing fibrosis after ionizing irradiation. Lab. Invest. 31:555-567.

23. Keith, I., R. Day, S. Lemaire, and I. Lemaire. 1987. Asbestos-induced fibrosis in rats: increase in lung mast cells and autocoid contents. Exp. Lung Res. 13:311-327

24. Choi, K. L., R. Giorno, and H. N. Claman. 1987. Cutaneous mast cell depletion and recovery in murine graft-vs-host disease. J. Immunol. 138:40934101 .

25. Dayton, E., J. Caulfield, A. Hein, K. Austen, and R. Stevens. 1989. Regulation of the growth rate of mouse fibroblasts by IL-3-activated mouse bone marrow-derived mast cells. J. Immunol. 142:4307-4313.

26. Claman, H. N. 1990. Mast cells and scleroderma. JAMA (J. Am. Med. Assoc.). 263:949.

27. Ruoss, S. J., T. Hartmann, and G. H. Caughey. 1991. Mast cell tryptase is a mitogen for cultured fibroblasts. J. Clin. Invest. 88:493-499.

28. Pennington, D. W., S. J. Ruoss, and W. M. Gold. 1992. Dog mastocytoma cells produce a growth factor for fibroblasts. Am. J. Respir. Cell Mol. Biol. In press.

29. Phillips, M., P. Barnes, and W. Gold. 1985. Characterization of purified dog mastocytoma cells. Am. Rev. Respir. Dis. 132:1019-1026.

30. Lazarus, S. C., R. DeVinney, L. J. McCabe, W. E. Finkbeiner, D. J. Elias, and W. M. Gold. 1986. Isolated canine mastocytoma cells: propagation and characterization of two cell lines. Am. J. Physiol. 251:C935-C944.

31. DeVinney, R., and W. M. Gold. 1990. Establishment of two dog mastocytoma cell lines in continuous culture. Am. J. Respir. Cell Mol. Biol. 3:413-420.

32. Danielpour, D., L. L. Dart, K. C. Flanders, A. B. Roberts, and M. B. Sporn. 1989. Immunodetection and quantitation of the two forms of transforming growth factor- $\beta$ (TGF $\beta 1$ and TGF $\beta 2$ ) secreted by cells in culture. J. Cell. Physiol. 138:79-86.

33. Graycar, J. L., D. A. Miller, B. A. Arrick, R. M. Lyons, H. L. Moses, and R. Derynck. 1989. Human transforming growth factor- $\beta 3$ : recombinant expression, purification, and biological activities in comparison with transforming growth factors- $\beta 1$ and $\beta 2$. Mol. Endocrinol. 3:1977-1986

34. Assoian, R. K. 1987. Purification of type- $\beta$ transforming growth factor from human platelets. Methods Enzymol. 146:153-163.

35. Chirgwin, J., A. Przbyla, R. MacDonald, and W. Rutter. 1979. Isolation of biologically active ribonucleic acid from sources enriched in ribonuclease. Biochemistry. 18:5294-5299.
36. Aviv, H., and P. Leder. 1972. Purification of biologically active globin messenger RNA by chromatography on oligothymidylic acid-cellulose. Proc. Natl. Acad. Sci. USA. 69:1408.

37. Derynck, R., J. A. Jarrett, E. Y. Chen, D. H. Eaton, J. R. Bell, R. K. Assoian, A. B. Roberts, M. B. Sporn, and D. V. Goeddel. 1985. Human transforming growth factor- $\beta$ complementary DNA sequence and expression in normal and transformed cells. Nature (Lond.). 316:701-705.

38. Miller, D. A., A. Lee, R. W. Pelton, E. Y. Chen, H. L. Moses, and R. Derynck. 1989. Murine transforming growth factor $\beta 2 \mathrm{cDNA}$ sequence and expression in adult tissues and embryos. Mol. Endocrinol. 3:1 108-1114.

39. Tso, J. Y., X.-H. Sun, T.-H. Kao, K. S. Reece, and R. Wu. 1985. Isolation and characterization of rat and human glyceraldehyde-3-phosphate dehydrogenase cDNAs: genomic complexity and molecular evolution of the gene. Nucleic Acids Res. 13:2485-2502.

40. Maniatis, T., E. Fritsch, and J. Sambrook. 1989. Molecular Cloning: A Laboratory Manual. Cold Spring Harbor Laboratory, Cold Spring Harbor, NY.

41. Thompson, N. L., K. C. Flanders, J. M. Smith, L. R. Ellingsworth, A. B Roberts, and M. B. Sporn. 1989. Expression of transforming growth factor $\beta 1$ in specific cells and tissues of adult and neonatal mice. J. Cell Biol. 108:661-669.

42. Broide, D. H., S. I. Wasserman, J. M. Alvaro-Garcia, N. J. Zvaifler, and G. S. Firestein. 1989. TGF $\beta 1$ selectively inhibits IL-3 dependent mast cell proliferation without affecting mast cell function or differentiation. J. Immunol. 143:1591-1597.

43. Crisp, A. J., C. M. Chapman, S. E. Kirkham, A. L. Schiller, and S. M Krane. 1984. Articular mastocytosis in rheumatoid arthritis. Arthritis Rheum 27:845-851.

44. Tomioka, M., T. Goto, T. D. G. Lee, J. Bienenstock, and A. D. Befus 1989. Isolation and characterization of lung mast cells from rats with bleomycininduced pulmonary fibrosis. Immunology 66:439-444.

45. Lawrence, D. A., R. Pircher, and P. Jullien. 1985. Conversion of a high molecular weight latent $\beta$-TGF from chicken embryo fibroblasts into a low molecular weight active $\beta$-TGF under acidic conditions. Biochem. Biophys. Res. Commun. 133:1026-1034.

46. Lyons, R. M., J. Keski-Oja, and H. L. Moses. 1988. Proteolytic activation of latent transforming growth factor- $\beta$ from fibroblast-conditioned medium. $J$. Cell Biol. 106:1659-1665.

47. Miyazano, K., and C.-H. Heldin. 1989. Interaction between TGF $\beta 1$ and carbohydrate structures in its precursor renders TGF $\beta 1$ latent. Nature (Lond.). 338:158-160.

48. Jennings, J. C., and S. Mohan. 1990. Heterogeneity of latent transforming growth factor- $\beta$ isolated from bone matrix proteins. Endocrinology. 126:10141021

49. Schechter, N. M., D. Slavin, R. D. Fetter, G. S. Lazarus, and J. E. Fraki. 1988. Purification and identification of two serine class proteinases from dog mast cells biochemically and immunologically similar to human proteinases tryptase and chymase. Arch. Biochem. Biophys. 262:232-244.

50. Dvorak, A. M., M. C. Mihm, and H. F. Dvorak. 1976. Morphology of delayed-type hypersensitivity reactions in man. Lab. Invest. 34:179-191.

51. Choi, K. L., and H. N. Claman. 1989. Mast cells in murine graft-versushost disease: a model of immunologically induced fibrosis. In Immune Mechanisms in Cutaneous Disease. D. A. Norris, editor. Marcel Dekker, Inc., New York. 641-651.

52. Ihle, J. N., J. Keller, S. Oronszlan, L. E. Henderson, T. D. Copeland, R. Fitch, M. B. Prystowsky, E. Goldwasser, J. W. Schrader, E. Palazynski, M. Dy, and B. Lebel. 1983. Biologic properties of homogenous interleukin 3. J. Immunol. 131:282.

53. Smith, D. M., and D. M. Rennick. 1986. Characterization of a murine lymphokine distinct from interleukin 2 and interleukin 3 (IL-3) possessing a T cell growth factor activity and a mast-cell growth factor activity that synergizes with IL-3. Proc. Natl. Acad. Sci. USA. 83:1857.

54. Moeller, J., L. Hultner, E. Schmitt, M. Breuer, and P. Dormer. 1990. Purification of MEA, a mast cell growth-enhancing activity, to apparent homogeneity and its partial amino acid sequencing. J. Immunol. 144:4231-4234.

55. Anderson, D., S. D. Lyman, A. Baird, J. M. Wignall, J. Eisenman, C. Rauch, C. J. March, H. S. Boswell, S. D. Gimpel, D. Cosman, and D. E. Williams. 1990. Molecular cloning of mast cell growth factor, a hematopoietin that is active in both membrane bound and soluble forms. Cell. 63:235-243.

56. Bressler, R. B., H. L. Thompson, J. M. Keffer, and D. D. Metcalfe. 1989. Inhibition of the growth of IL-3-dependent mast cells from murine bone marrow by recombinant granulocyte-macrophage colony-stimulating factor. J. Immunol. 143:135-139.

57. Kanakura, Y., A. Kuriu, N. Waki, T. Nakano, H. Asai, T. Yonezawa, and Y. Kitamura. 1988. Changes in numbers and types of mast cell colony-forming cells in the peritoneal cavity of mice after injection of distilled water: evidence that mast cells suppress differentiation of bone marrow-derived precursors. Blood. 71:573-580.

58. Chaikin, E., H. J. Ziltener, and E. Razin. 1990. Protein kinase C plays an inhibitory role in interleukin 3- and interleukin 4- mediated mast cell proliferation. J. Biol. Chem. 265:22109-22116. 